\title{
ANALYSIS OF THE ASSOCIATION BETWEEN SRA1 RS801460 POLYMORPHIC VARIANT AND THYROID NODULES OCCURRENCE IN UKRAINIAN WOMEN WITH PROLIFERATIVE TYPE OF BENIGN BREAST DYSPLASIA WITHOUT ATYPIA
}

Authors: Kolnoguz $A^{1}$, Lukavenko I ${ }^{1}$, Harbuzova $V^{1}$ (mentor)

${ }^{1}$ Sumy State University, Medical Institute, Sumy, Ukraine

DOI: https://doi.org/10.26800/LV-142-supp5-48

\section{Introduction}

It was revealed the association between oncological processes in mammary and thyroid glands. The steroid receptor RNA activator 1 (SRA1) is a long non-coding RNA that can act through the steroid hormone receptors transactivation. Thus, a potential role for SRA1 in the pathogenesis of hormonesensitive tissues tumors is suggested.

\section{Aim of the study}

To study the possible link between SRA1 gene rs801460-polymorphism and thyroid nodules (TN) in Ukrainian women with proliferative type of benign breast dysplasia (BBD) without atypia.

\section{Materials and methods}

Whole venous blood of 117 Ukrainian women with proliferative type of BBD without atypia was used for the study. Genotyping of SRA1 rs801460 polymorphic variant was performed using polymerase chain reaction-restriction fragment length polymorphism analysis (PCR-RFLP). The SPSS software package (version 25.0) was used for mathematical analysis.

\section{Results}

It was found the following genotypes frequencies in patients with and without $\mathrm{TN}$ : $\mathrm{C} / \mathrm{C}-8.3 \%, \mathrm{C} / \mathrm{T}-$ $91.7 \%, \mathrm{~T} / \mathrm{T}-0 \%$ and $\mathrm{C} / \mathrm{C}-36.2 \%, \mathrm{C} / \mathrm{T}-48.6 \%, \mathrm{~T} / \mathrm{T}-15.2 \%$ respectively. There was a statistically significant differences in genotypes distribution $\left(X^{2}=8.110 ; P=0.017\right)$. It was revealed a significant association between SRA1 rs801460-polymorphism and thyroid nodules under crude over-dominant model of inheritance $(P=0.021, O R=0.086,95 \% \mathrm{Cl}=0.011-0.689)$ and after the adjustment for age and $\mathrm{BMI}(\mathrm{P}=0.020, \mathrm{OR}=0.083,95 \% \mathrm{Cl}=0.010-0.681)$.

\section{Conclusion}

Statistically significant association was found between SRA1 rs801460-polymorphism and thyroid nodules development in Ukrainian females with proliferative type of BBD without atypia. Patients with $\mathrm{C} / \mathrm{T}$-genotype have less risk of thyroid nodules occurrence compared to homozygotes ( $\mathrm{C} / \mathrm{C}$ and $\mathrm{T} / \mathrm{T}$ ).

Keywords: rs801460-polymorphism, SRA1, thyroid nodule. 